\title{
Angolatitan adamastor, a new sauropod dinosaur and the first record from Angola
}

\author{
OCTÁVIO MATEUS ${ }^{1,2}$, LOUIS L. JACOBS ${ }^{3}$, ANNE S. SCHULP ${ }^{4}$, MICHAEL J. POLCYN ${ }^{3}$, \\ TATIANA S. TAVARES ${ }^{5}$, ANDRÉ BUTA NETO ${ }^{5}$, MARIA LUÍSA MORAIS ${ }^{5}$ and MIGUEL T. ANTUNES \\ ${ }^{1}$ CICEGe, Faculdade de Ciências e Tecnologia, FCT, Universidade Nova de Lisboa, 2829-516 Caparica, Portugal \\ ${ }^{2}$ Museu da Lourinhã, Rua João Luis de Moura, 2530-157 Lourinhã, Portugal \\ ${ }^{3}$ Huffington Department of Earth Sciences, Southern Methodist University, Dallas, TX, 75275, USA \\ ${ }^{4}$ Natuurhistorisch Museum Maastricht, de Bosquetplein 6-7, NL6211 KJ Maastricht, The Netherlands \\ ${ }^{5}$ Geology Department, Universidade Agostinho Neto, Av. 4 Fevereiro, Luanda, Angola \\ ${ }^{6}$ Academia de Ciências de Lisboa, Rua da Academia das Ciências, 19, 1242-122 Lisboa, Portugal \\ Manuscript received on October 19, 2009; accepted for publication on June 21, 2010
}

\begin{abstract}
A forelimb of a new sauropod dinosaur (Angolatitan adamastor n. gen. et sp.) from the Late Turonian of Iembe (Bengo Province) represents the first dinosaur discovery in Angola, and is one of the few occurrences of sauropod dinosaurs in sub-Saharan Africa collected with good chronological controls. The marginal marine sediments yielding the specimen are reported to be late Turonian in age and, thus it represents a non-titanosaurian sauropod in sub-Saharan Africa at a time taken to be dominated by titanosaurian forms. Moreover, Angolatitan adamastor is the only basal Somphospondyli known in the Late Cretaceous which implies in the existence of relict forms in Africa.
\end{abstract}

Key words: Angola, Cretaceous, Turonian, Dinosaurs, Sauropoda, Angolatitan.

\section{INTRODUCTION}

Although very rich in Cretaceous vertebrates, Angola has remained unexplored in recent decades. Beginning in 2005, the field work conducted by the PaleoAngola Project has significantly enhanced the palaeontological record of the Cretaceous of Angola (Jacobs et al. 2006, 2009a, b, Polcyn et al. 2009, Mateus et al. 2008, Schulp et al. 2008). The PaleoAngola Project mounted the first systematic paleontological expeditions that have been conducted since the early 1960s, when Miguel Telles Antunes performed an extensive and systematic survey on the Angolan fossil vertebrate fauna the most relevant work published in 1964 (Antunes 1964). In May 2005 we (O.M. and L.J.) prospected the coastal area near Iembe which resulted in the discovery, in May, 25th (by

Proceedings of the Third Gondwanan Dinosaur Symposium Correspondence to: Octávio Mateus

E-mail: omateus@fct.unl.pt
$\mathrm{OM}$ ), of the new taxon reported here. Follow-up excavations were performed in May and August 2006. To our knowledge, it was the only systematic prospecting for fossil vertebrates in this area since 1960 by M. Telles Antunes (in September) and M. Mascarenhas Neto.

While the lush vegetation in most inland areas precludes fossil prospecting, the exposures along the Atlantic coastline in Ambriz municipality allows systematic prospecting. The material collected by the PaleoAngola Project is largely housed at Museu Geológico da Universidade Agostinho Neto (MGUAN) in Luanda, while some of the collected mosasaur, plesiosaur, pterosaur, and turtle specimens are temporarily housed at Museu da Lourinhã (ML), Portugal, and Southern Methodist University (SMU) in Dallas, to be returned to Angola after preparation and study. 


\section{Geology And Associated Fauna}

The term 'Tadi beds' was first coined in the 1960 unpublished study of G. Brognon, G. Verrier, and R Thiers "Géologie du Bassin du Cuanza et du Bas-Congo" from the "Missão de Pesquisas de Petróleo Petrofina". It was accepted and used by Antunes (1964) and Antunes and Cappetta (2002). The original study considered the 'Tadi Beds' to represent the base of the 'Senonian' (= Coniacian), but the fish fauna led Antunes (1961, 1964: 56) to consider the Tadi Beds to be of late Turonian age. In a revision of the Cretaceous selachians of Angola, Antunes and Cappetta (2002: 95) reconfirm the late Turonian age of these beds, and place them in the 'Itombe Formation' (see also Jacobs et al. 2006). The Tadi Beds are about $50 \mathrm{~m}$ thick (Antunes 1964: 56). G. Brognon et al. (cited in Antunes 1964: 56) provide a list of the invertebrate fauna, including the ammonite genera Hemitissotia, Romaniceras and Pachydiscus, and echinoderms. The fish and shark fauna (Antunes and Cappetta 2002: 95) includes Hexanchus cf. microdon, Ptychodus mortoni, P. cf. paucisulcatus, P. whipplei, Scapanorhynchus raphiodon, S. cf. lewesii, Cretodus semiplicatus, Cretodus sp., Cretoxyrhina mantelli, Paranomotodon angustidens, Squalicorax falcatus, Squalicorax sp., Onchosaurus pharaoh, and Enchodus cf. elegans.

The tetrapod fauna from the Iembe locality (Antunes 1964, Jacobs et al. 2006; and new unpublished data) includes an eucryptodiran turtle Angolachelys mbaxi (Mateus et al. 2009), the mosasaurs Angolasaurus bocagei Antunes 1964 (see also Polcyn et al. 2009) and Tylosaurus iembeensis (Antunes 1964, LinghamSoliar 1992), Plesiosauria indet., and the sauropod material described here. The discovery here reported is the first dinosaur and the first Cretaceous terrestrial animal from Angola.

\section{SYSTEMATICS PALEONTOLOGY}

Dinosauria Owen, 1842

Sauropoda Marsh, 1878

Neosauropoda Bonaparte, 1986

Titanosauriformes Salgado et al., 1997

Somphospondyli Wilson and Sereno, 1998

Angolatitan adamastor n. gen., n. sp.

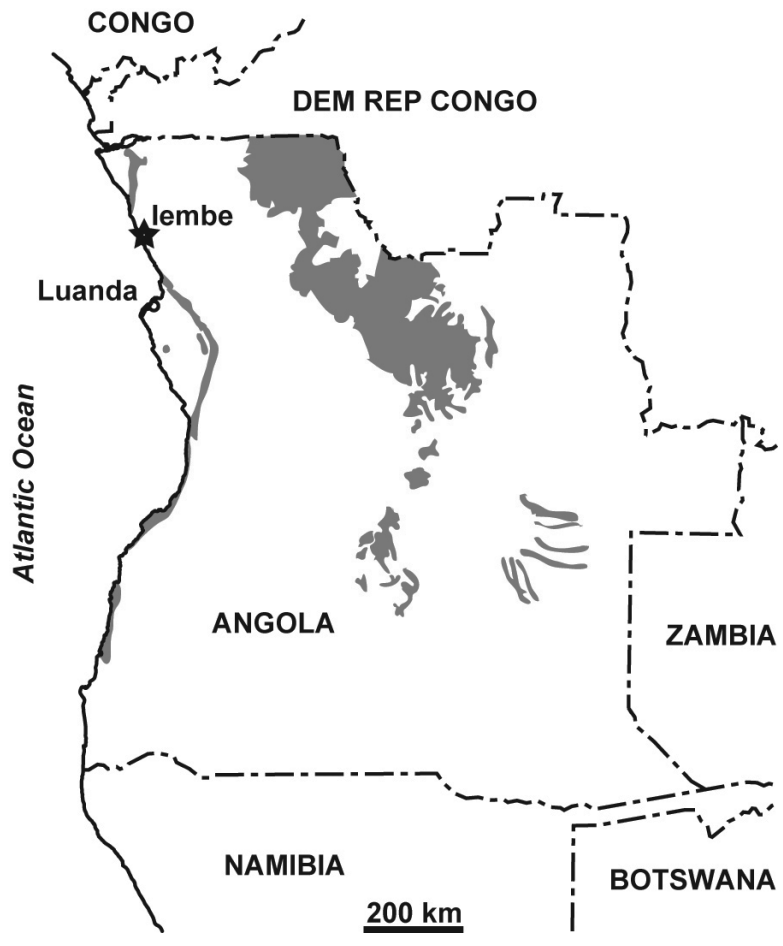

Fig. 1 - Map of Angola, showing the Tadi site (star; $08^{\circ} \mathrm{S} / 13^{\circ} \mathrm{E}$ ) and the distribution of Cretaceous strata (grey) in Angola.

\section{ETYMOLOGY}

Angolatitan means Angolan giant. Adamastor was a mythological sea giant from the South Atlantic feared by the Portuguese sailors.

\section{Generic AND SPECIFIC Diagnosis}

Titanosauriform sauropod with: posteroventral eminence in scapula in the proximal one-quarter, anterior to the acromial ridge; acute medioproximal margin of humerus; and rectangular lateral corner of proximal humerus; proximal outline of the ulna with anteromedial ridge (process); posterior facet of the distal epiphysis of metacarpal I with two small splint-like projections (Figs. 3 and 5).

\section{TYPE LOCALITY AND HORIZON}

Tadi, near Iembe, Tábi community, municipality of Ambriz, Bengo Province, Angola. The precise coordinates of collecting sites are on file at the participating institutions.

Tadi Beds, Itombe Formation, Late Turonian (around 90 M.a.), Late Cretaceous. 


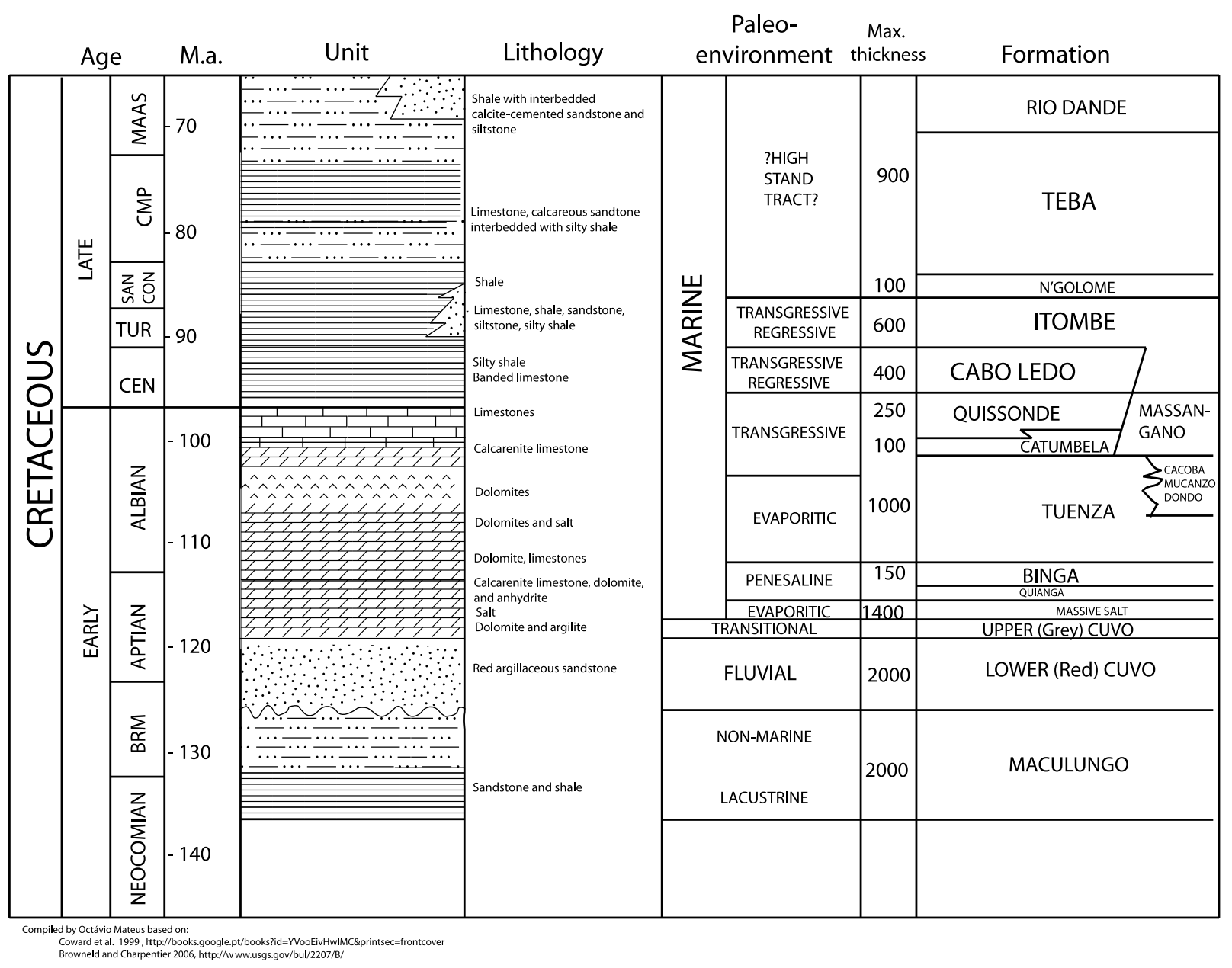

Fig. 2 - Summary of the geology of the Cretaceous of Kwanza Basin (Angola) based on Brownfield and Charpentier (2006) and Coward et al. (1999).

\section{MATERIAL}

The material includes a partial right forelimb including the scapula, humerus, ulna, radius and metacarpals I, III, and IV (Table I). All material described here is curated at Museu de Geologia da Universidade Agostinho Neto - PaleoAngola Project, Luanda, Angola (MGUAN-PA), and temporarily registered under field number MGUANPA-003 (replicas will be housed at Museu da Lourinhã, Portugal, and at Southern Methodist University, USA).

\section{DESCRIPTION}

The scapula is missing its posterior end and part of its proximal expansion. The preserved length is $95 \mathrm{~cm}$, but it is estimated to have been $105 \mathrm{~cm}$ if complete. The scapula is overall straight rather than bowed medially.
However, this could be a case of taphonomical distortion. The proximal end is incomplete, but does not seem very expanded. The scapular blade is $16.5 \mathrm{~cm}$, with the ventral supraglenoid expansion just above it, and $24 \mathrm{~cm}$ on the maximum dorsal expansion. The ventral supraglenoid expansion is $65 \mathrm{~cm}$ in its maximum anteroposterior width, therefore representing nearly four times the minimum width of the blade. For the description, the orientation of the scapula adopted here is with the scapular blade in a vertical dorsal position as in Romer (1956).

The blade is rectangular in cross section, with thicker anterior margin. The anterior margin (acromial side) is bowed anteriorly in lateral view, while the posterior rim is nearly straight, except for the ventral portion that expands posteriorly. The acromion strongly projects 

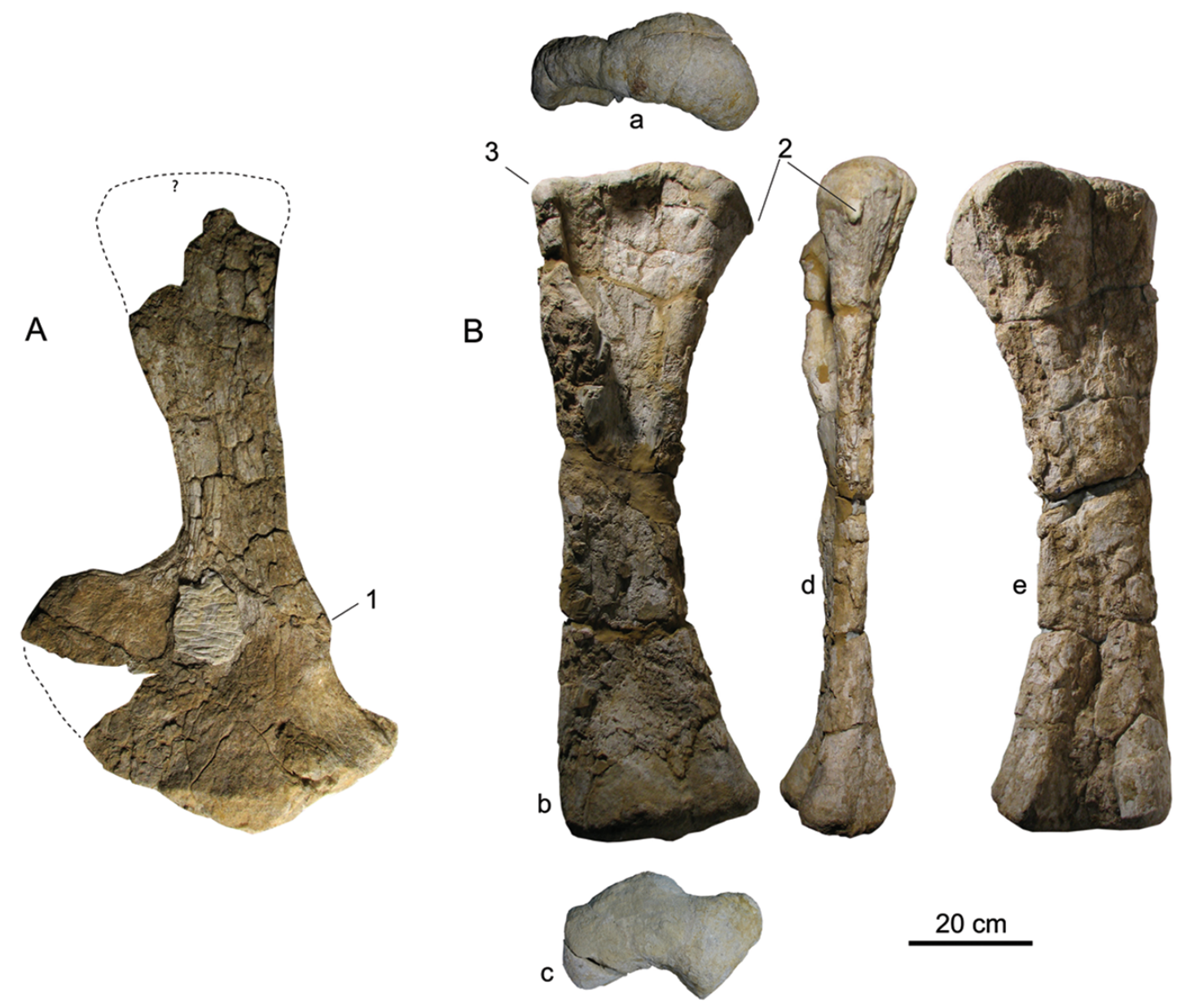

Fig. 3 - Angolatitan adamastor n. gen. et sp., A) right scapula in medial view; B) right humerus in proximal(a), anterior (b), distal (c), medial (d), and posterior (e) views. Autapomorphic features: 1, posteroventral eminence in scapula in the proximal one-quarter, anterior to the acromial ridge; 2, acute medioproximal margin of humerus; and 3, rectangular lateral corner of proximal humerus.

anteriorly, forming a gentle curve in its anterodorsal corner due to the absence of the dorsal hook.

The medial surface is gently concave in all its extension, except in a small $(\mathrm{ca} .6 \mathrm{~cm}$ ) shallow bump placed at the anterior part at the base of the scapular blade, and in the bump in the posteromedial margin of the scapula about $20 \mathrm{~cm}$ above the glenoid.

The contact surface between the coracoid and glenoid is perpendicular with the blade in a posterior or anterior perspective, but the contact with the coracoid runs slightly dorsally, forming a $20^{\circ}$ angle with the horizontal (if the scapula is arranged upwards). The glenoid is flat, facing ventrally, but the medial portion, near the midline, bevelled slightly medially, forming an area facing ventromedially. A strongly bevelled medi- ally glenoid is apomorphic of Somphospondyli according to Wilson 2002 (character 153).

The ventroposterior margin of the scapula, adjacent to the glenoid, projects posteriorly and has a small (ca. $9 \mathrm{~cm}$ ) vertical ridge that borders a groove somewhat similar to Cetiosaurus oxoniensis. A posteroventral bump in the scapula in the proximal one-quarter is shared/convergent with Dystrophaeus and Supersaurus, Ultrasaurus mcintoshi, Lourinhasaurus alenquerensis, and Camarasaurus supremus, but, unlike other sauropods, it is anterior to the acromial ridge. The glenoid foramen is not visible.

Except for a portion of the humeral head, the right humerus is complete, but the surface preservation is poor, particularly at the diaphysis, being moderately 

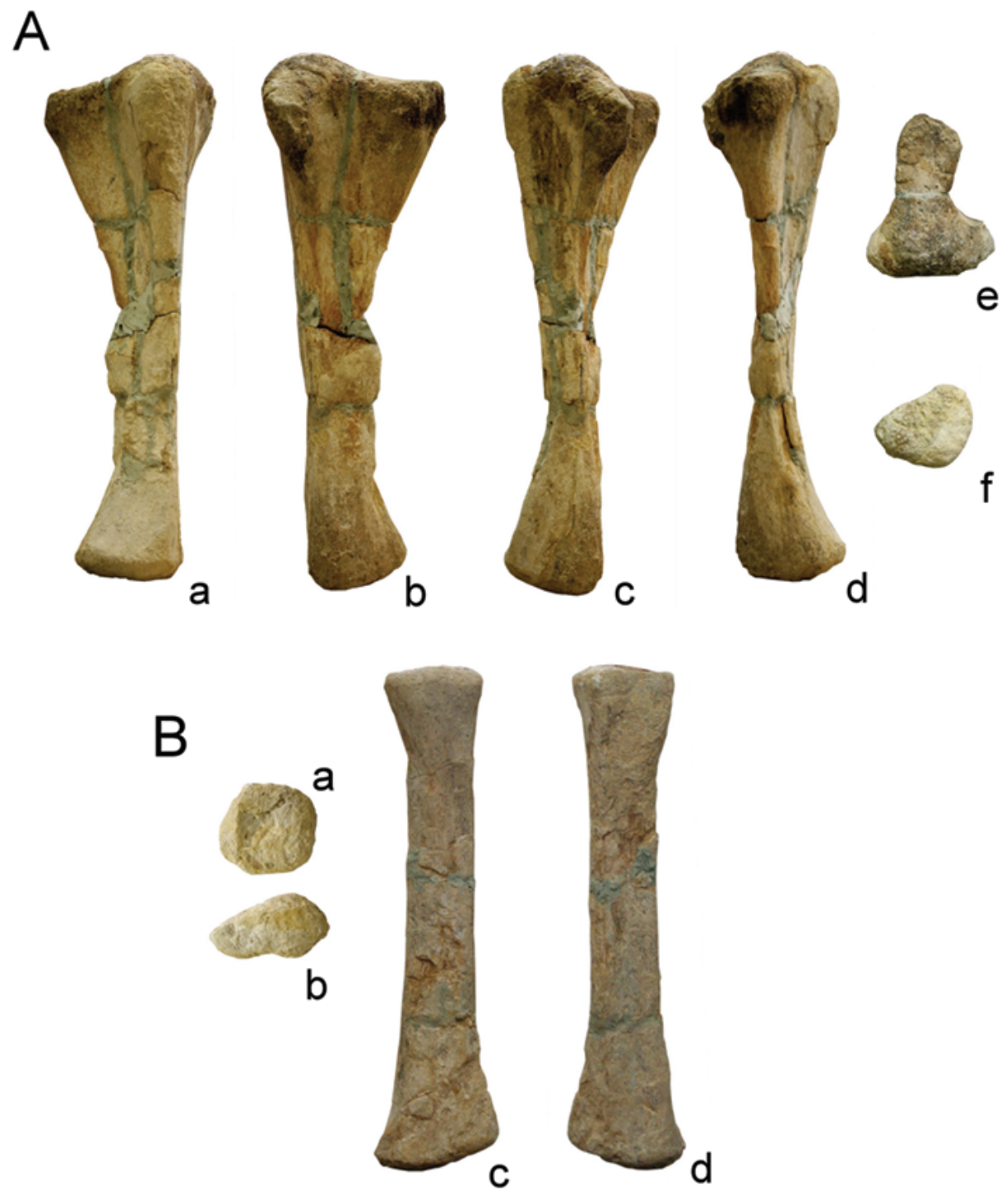

Fig. 4 - Angolatitan adamastor n. gen. et sp., A) right ulna in medial (a), anterior (b), lateral (c), posterior (d), proximal (e) and distal (f) views; and (B) right radius in proximal (a), distal (b), anterior (c), and posterior (d) views.

gracile with a straight shaft. The proximal end is Lshaped due to the well-defined deltopectoral crest. The humeral head is well developed and more projected anteriorly than the lateral corner, which gives an asymmetrical outline in anterior view. The lateral corner forms a rectangular corner (rather than a round corner more commonly seen in sauropods) and a straight line to the most proximal part of the humerus. The medioproximal corner of the humerus is very pointy due to a $4 \mathrm{~cm}$ triangular lateral projection, which is autapomorphic. The triangular deltopectoral crest extends along nearly the upper half of the anterior aspect of the lateral margin. The tip of the deltopectoral crest projects well anteromedially, invading the anterior side of the shaft. A medially projected deltopectoral crest is present in Titanosauriformes more derived than Brachiosaurus. The bump placed lateromedially to the tip of deltopectoral crest gently projects laterally, making a wide area for muscle attachment. Except for this bump, the lateral margin is totally straight. A hemispherical humeral head projects well posteriorly. The diaphyseal cross section is tabular, with convex and concave, posterior and anterior faces, respectively. The two prominent condyles (ulnar and radial) are well defined in the distal epiph- 


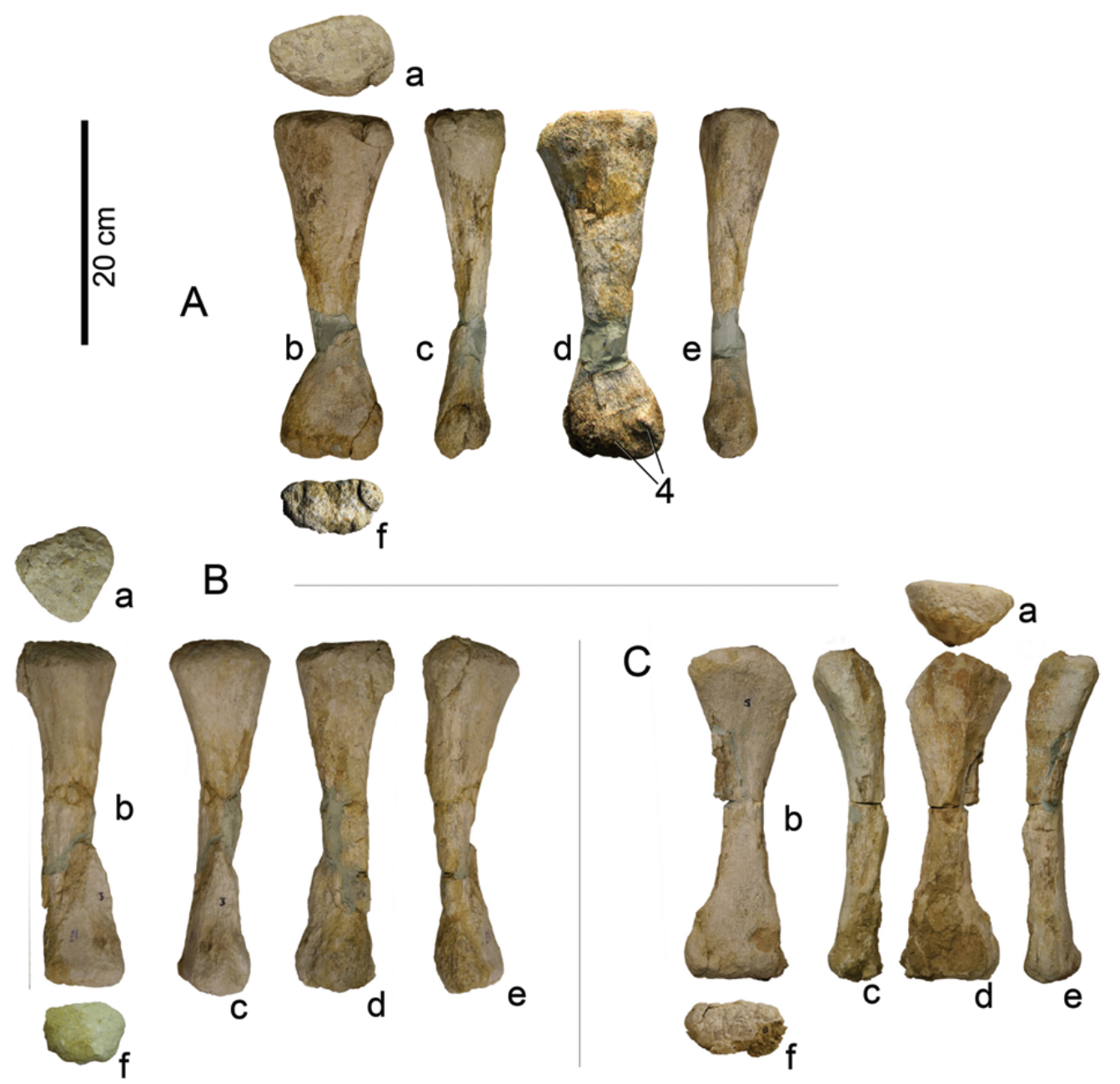

Fig. 5 - Angolatitan adamastor n. gen. et sp., right metacarpals I (A), III (B) and IV (C), in proximal (a), anterior (b), medial (c), palmar (d), lateral (e), and distal (f) views. 4, posterior facet of the distal epiphysis of metacarpal I has two small splint-like projections (autapomorphy).

ysis, being well separated by posterior and anterior intercondylar grooves. The distal articular facet is slightly convex, nearly planar, without condylar expression. At the anterior face, the distal condyles are directed anteromedially without significant dorsal projection. There is a vertical groove between the lateral condyle and the lateral margin, that creates a notch aspect in distal view. In the posterior face, the lateral condyle is round, while the medial condyle forms an acute vertical edge. The posterior intercondylar groove is wide and deep.

The right ulna is complete, except for a small part of the lateral face of the diaphysis. The general aspect is gracile. It measures $69 \mathrm{~cm}$ in length, $23 \mathrm{~cm}$ at its maximum proximal expansion, and $14.5 \mathrm{~cm}$ in width at its distal expansion. In proximal view, the ulna bears a tri-radiate outline, with prominent anterolateral and anteromedial processes, and a less-developed posterior process. The proximal outline shows an expanded anteromedial ridge (process) constricted in the base. The anteromedial ridge is nearly twice the lateral one. The olecranon process is poorly developed and does not projects significantly more proximally than the anteromedial one. The shaft is moderately straight and less robust than in most titanosaurs. The distal epiphysis is sub-round to sub-triangular, with a slight transverse expansion.

The right radius is complete, measuring $63 \mathrm{~cm}$ in length. The bone is gracile and straight, with moderate 
TABLE I

Measurements of Angolatitan adamastor (in cm).

\begin{tabular}{l|c|c|c|c}
\hline & Length & $\begin{array}{c}\text { Minimal diaphyseal } \\
\text { circumference }\end{array}$ & $\begin{array}{c}\text { Maximal proximal } \\
\text { expansion }\end{array}$ & $\begin{array}{c}\text { Maximal distal } \\
\text { expansion }\end{array}$ \\
\hline Scapula & 95 & - & 61 & - \\
\hline Humerus & 110 & 43.2 & 36 & 29 \\
\hline Ulna & 69 & $27^{*}$ & 23 & 14.5 \\
\hline Radius & 63 & 22.5 & 16.5 & 13 \\
\hline Metacarpal I & 30.0 & - & 10.5 & $8.5^{*}$ \\
\hline Metacarpal III & 30.9 & $13^{*}$ & 9 & $8.5^{*}$ \\
\hline Metacarpal IV & 28.5 & 12 & $9 *$ & - \\
\hline
\end{tabular}

*Estimated.

epiphyseal expansions. The maximum proximal width equals about $25 \%$ of the full length of the radius. The proximal end is sub-round, while the distal end is flattened and elongated with an anteroposterior expansion. The medial edge of the distal epiphysis is acute, but the lateral is round. The posterior face of the distal epiphysis bears a groove at the ulnar articulation procuding two shallow posterior condyles. The medial part projects more distally forming a bevelled angle with the main shaft.

Three metacarpals (I, III and IV) were present near the distal end of the ulna. With the exception of the bone surfaces exposed to weathering prior to discovery, the bones do not show signs of crushing or deformation. The metacarpal position was identified as I, III, and IV using Janensch (1961), Apesteguía (2005) and Bonnan and Wedel (2004). The metacarpals are elongated, much more than in titanosaurs. All metacarpals are nearly of the same size, but III is the largest and IV is the shortest preserved element. The distal end bears sutble but separated distal condyles which is a plesiomorphic condition because the presence of divided condyles is normally associated with the presence of phalanges, lost in titanosaurs (Wilson 2002, Upchurch et al. 2004). The metacarpals bound together by the extensive diaphyseal articulation to form a tubular arrangement, U-shaped in proximal view. The length ratio between metacarpal III and the radius is 0.48 . A ratio higher than 0.45 is used to be considered a character for Macronaria.

Metacarpal I is robust, with proximal outline palmodorsally flattened forming a D-shape outline, and the medial corner more rounded than the lateral. The metacarpal presents a crest along the whole lateral facet and with a sinosoidal area at midshaft. The distal end is transversely broad, with two well-defined condyles (but less visible than in non-macronarian sauropods) divided by distal and posterior grooves, the lateral condyle being smaller than the medial. The posterior facet of the distal epiphysis has two small splint-like projections: one just above the intercondylar groove and the other near the lateral condyle, which is autapomorphic.

The right metacarpal III is complete, with the exception of a portion of the lateral distal condyle. It is subtriangular in proximal view. Ligament attachments on the palmar surface occupy almost the entire proximal half of the metacarpal - which also represents the area of contact with metacarpal IV. The medial facet has an acute crest along the diaphysis that is divided in the proximal third, and rims a large facet facing anteromedially. The distal end shows defined condyles, being the lateral one the largest.

The metacarpal IV is robust. In the proximal view it is triangular, with the anterior margin being the widest. The proximal surface is flat, but the dorsomedial corner which is projected medially deflects distally forming a $45^{\circ}$ angle with the proximal surface. The distal end is transversely broad and presents two condyles divided by a medial vertical intercondylar groove, but there is no distal intercondylar groove. This bone resembles the metacarpal IV of cf. Laplatasaurus figured by Apesteguía (2005: Fig. 15.4.G), which is anormally slender for a Titanosauridae (see Apesteguía 2005, Table 15.2). 
There are no signs of other carpals, metacarpals or phalanges, but the lateral flattening on metacarpal IV suggests the possible presence of metacarpal V, and the distal condyles suggest the presence of phalanges.

\section{COMPARISONS AND PHYLOGENY}

The olecranon process of the ulna is more proximally projected than in Jurassic sauropods Lourinhasaurus, Lusotitan, Apatosaurus, Camarasaurus, and Diplodocus, but less than in most Titanosauria, when compared with Saltasaurus loricatus "Titanosaurus" colberti), Tornieria robusta (Janensch 1961), Epachthosaurus sciuttoi (Martínez et al. 2004), and Malawisaurus dixeyi (Gomani 2005), and somehow with the same extension as in Rapetosaurus krausei (Curry Rogers 2009). Ulna robustness (proximal width/length) is 0.33 in Angolatitan adamastor, which is lower than 0.35 in Lusotitan atalaiensis, 0.35 in aff. Turiasaurus ML368, 0.36 in Malawisaurus dixeyi (Gomani 2005: Table 7), 0.34 in Rapetosaurus krausei (Curry-Rogers 2009: Table 3), and strikingly lower than 0.41-0.43 in Epachthosaurus sciuttoi (Martínez et al. 2004: Table 2). The data for establishing the robustness is unreported or unknown in most titanosaurs (e.g. Limaysaurus tessonei, Rinconsaurus cadamirus, Muyelensaurus pecheni, and Saltasaurus loricatus), for which the ulnae is clearly more robust. Wilhite (2003) provides measures for many Late Jurassic ulnae, which, in average, gives the following means for robustness: 0.40 for Apatosaurus, 0.23 for Barosaurus, 0.39 for Brachiosaurus, 0.38 for Camarasaurus, and 0.33 for Diplodocus.

In Angolatitan adamastor, the metacarpals do not show three titanosaurian characters considered by Apesteguía (2005): bowed metacarpal I, the flat distal metacarpal trochlea (although this is difficult to quantify), and reduced intermetacarpal contact that is $1 / 6$ of the metacarpal length.

The data matrix was based in Wilson (2002), but the integration of characters in Upchurch et al. (2004) for the forelimb (Angolatitan coding using Wilson 2002, characters 150 to 200: 10000 ????10 01011100101 1???111100 ?????????? ??????????, and Upchurch et al. 2004, characters 200 to 250: 1100001 ???? ??????0101 101000?11? 101?11????). The matrix was processed using WinClada ver 1.0 (www.cladistics.com) using a heuristic search with 100 replicates. Angolatitan adamastor n.gen. et sp. was placed as a basal titanosauriform Somphospondyli more derived than Brachiosaurus, but less derived than Euhelopus (see Fig. 6). The metacarpals are slender (close to Camarasaurus proportions and alike titanosaurs as Opisthocoelicaudia, when compared in the plot provided by Bonnan and Wedel 2004). The robustness (ratio minimum diaphyseal perimeter/length) is 0,42 , which is lower than the range of 0,5-0,6 in most titanosaurs (Apesteguía 2005: Table 15.2). The size of metacarpals is equivalent (being of variable length in Titanosauridae, see Apesteguía 2005), and the distal end is round, rather than flat as in Titanosauridae.

The Angolatitan adamastor is supported as Somphospondyli by the following unambiguous synapomorphies: humeral square proximolateral corner (character 159 in Wilson 2002), deltopectoral crest medially expanded across the cranial face of the humerus (ch. 220 in Upchurch et al. 2004), and distalmost part of the caudal surface of the humerus deeply concave between the lateral and medial prominent vertical ridges (ch. 221 in Upchurch et al. 2004). However, the scapular glenoid surface faces cranioventrally (ch. 203 in Upchurch et al. 2004) unlike Euhelopus and other derived Somphospondyli. The Angolan sauropod does not bear titanosaurian synapomorphies such as the ulna with prominent olecranon process (Wilson 2002: character 167) or extremely robust ulna and radius (Upchurch et al. 2004: 309).

\section{GeOgRAPHY AND Chronology}

Although sauropod dinosaurs have been reported from elsewhere in Africa, (e.g. Algeria, Cameroon, Egypt, Kenya, Malawi, Mali, Morocco, Niger, South Africa, Sudan, Tunisia, Zambia, Zimbabwe, and Madagascar), no others are known from the Late Turonian. The only described Late Cretaceous sauropods from Africa are the lithostrotian titanosaurs Aegyptosaurus baharijensis from Egypt and Niger (Stromer 1932; early Cenomanian) and Paralititan stromeri from Egypt (Smith et al. 2001; early Cenomanian), the diplodocoid cf. Dicraeosaurus from Egypt (Smith et al. 2001), and Rapetosau- 


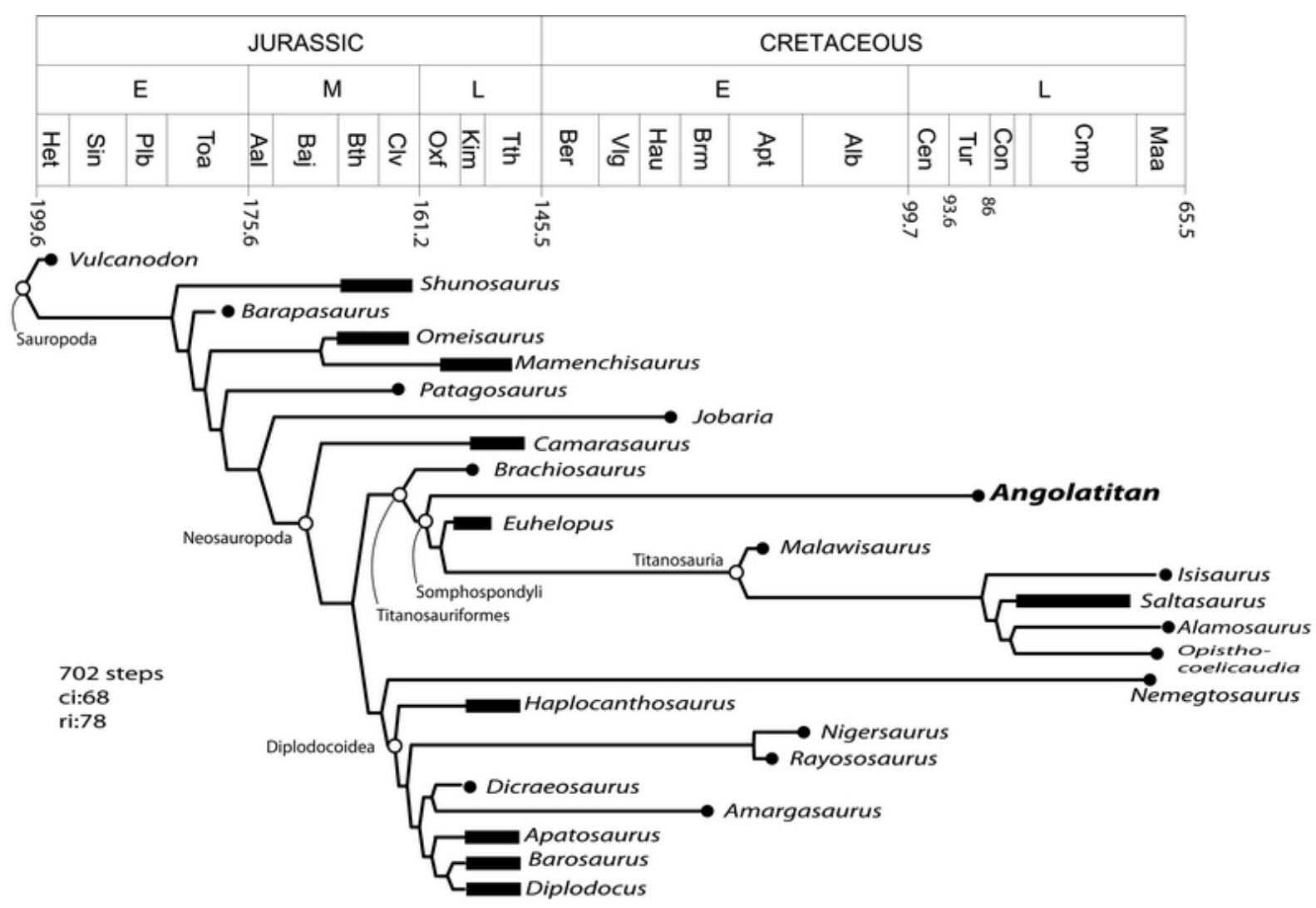

Fig. 6 - Phylogenetic relationships of Angolatitan adamastor and other sauropods. See text for explanation.

rus krausei and "Titanosaurus" madagascariensis from Madagascar (Campanian; Curry Rogers and Forster 2001, Weishampel et al. 2004). Globally, the circaTuronian sauropods were found only in Argentina, Brazil, and China (Table II), and comprise mostly titanosaurs or diplodocoids. Thus, A. adamastor fills a 15My gap in the African sauropod record, and an even wider gap in the global record of non-titanosaur sauropods.

Non-titanosaur sauropods, which were dominant during the Jurassic, were being replaced by titanosaurs and derived diplodocoids, becoming rarer in the Late Cretaceous when most identifiable African sauropods were titanosaurs. The reasons for the late Cretaceous dominance of titanosaurs over other sauropods are not fully understood, but it seems to be a general pattern in South America, in Madagascar, and probably in Africa as well.

Although some scarce remains of non-titanosaurs are known, the relevance, distribution, paleogeography, chronology and even taxonomy of these sauropods is not well understood for the Late Cretaceous of Africa. Diplodocoids were the most successful non-titanosaur sauropods in the Cretaceous, but the presence of possible brachiosaurids (Rauhut and Werner 1997) raises questions regarding the paleogeography of sauropods.

The age of the sediments yielding the specimen is Upper Turonian ( 90Ma) based on the fish and shark teeth (Antunes and Cappetta 2002) and, thus, is one of the best-dated Late Cretaceous sauropod specimens in sub-Saharan Africa. Further work in this area, in part based on ammonites collected with the specimen, will almost certainly provide refined chronology and paleogeography of the Late Cretaceous dinosaur fauna of Africa.

During the Late Turonian, the coast of Iembe (now at $8^{\circ} \mathrm{S}$ latitude) was at about $24^{\circ} \mathrm{S}$ latitude due to the drift of Africa southeastwards until 100 M.a. and northeastwards since then (Jacobs et al. 2009a, Fig. 2). Such paleolatitudes fall into the arid latitudinal band between 
TABLE II

Circa-Turonian sauropod species.

\begin{tabular}{|c|c|c|c|c|c|c|}
\hline Taxon & Country & Early_stage & Late_stage & Reference & Systematics & \\
\hline $\begin{array}{c}\text { Andesaurus } \\
\text { delgadoi }\end{array}$ & Argentina & Albian & Turonian & $\begin{array}{c}\text { Calvo and Bonaparte } \\
\text { 1991, Calvo } 1999\end{array}$ & Titanosauria & Humerus \\
\hline $\begin{array}{c}\text { Argentinosaurus } \\
\text { huinculensis }\end{array}$ & Argentina & Albian & Turonian & $\begin{array}{c}\text { Bonaparte and } \\
\text { Coria } 1993\end{array}$ & Titanosauria & Unknown \\
\hline $\begin{array}{l}\text { Argyrosaurus } \\
\text { superbus }\end{array}$ & Argentina & Cenomanian & Turonian & Huene 1929 & Titanosauria & $\begin{array}{l}\text { Complete } \\
\text { forelimb }\end{array}$ \\
\hline $\begin{array}{c}\text { Borealosaurus } \\
\text { wimani }\end{array}$ & China & Cenomanian & Turonian & You et al. 2004 & ?Opisthocoelicaudiinae & Humerus \\
\hline $\begin{array}{c}\text { Cathartesaura } \\
\text { anaerobica }\end{array}$ & Argentina & Cenomanian & Coniacian & $\begin{array}{c}\text { Gallina and } \\
\text { Apesteguía } 2005\end{array}$ & Rebbachisauridae & $\begin{array}{l}\text { Scapula and } \\
\text { femur }\end{array}$ \\
\hline $\begin{array}{c}\text { Dongyangosaurus } \\
\text { sinensis }\end{array}$ & China & Cenomanian & Santonian & Lü et al. 2008 & Titanosauria & Unknown \\
\hline $\begin{array}{c}\text { Epachthosaurus } \\
\text { sciuttoi }\end{array}$ & Argentina & $\begin{array}{c}\text { Late } \\
\text { Cenomanian }\end{array}$ & $\begin{array}{c}\text { Early } \\
\text { Turonian }\end{array}$ & Martínez et al. 2004 & Titanosauria & $\begin{array}{l}\text { Complete } \\
\text { forelimb }\end{array}$ \\
\hline $\begin{array}{c}\text { Futalognkosaurus } \\
\text { dukei }\end{array}$ & Argentina & $\begin{array}{c}\text { Late } \\
\text { Turonian }\end{array}$ & $\begin{array}{c}\text { Early } \\
\text { Coniacian }\end{array}$ & Calvo et al. $2007 \mathrm{a}$ & Titanosauria & Unknown \\
\hline $\begin{array}{c}\text { Gondwanatitan } \\
\text { faustoi }\end{array}$ & Brazil & Turonian & Santonian & $\begin{array}{c}\text { Kellner and } \\
\text { Azevedo } 1999\end{array}$ & Lithostrotia & Humerus \\
\hline $\begin{array}{c}\text { Huabeisaurus } \\
\text { allocotus }\end{array}$ & China & Cenomanian & Maastrichtian & $\begin{array}{c}\text { Pang and } \\
\text { Cheng } 2000\end{array}$ & Titanosauria & $\begin{array}{l}\text { Scapula, coracoid, } \\
\text { humerus, radius }\end{array}$ \\
\hline $\begin{array}{l}\text { Huanghetitan } \\
\text { ruyangensis }\end{array}$ & China & Cenomanian & Santonian & Lü et al. 2007 & Titanosauriformes & Unknown \\
\hline $\begin{array}{c}\text { Limaysaurus } \\
\text { tessonei }\end{array}$ & Argentina & Albian & Turonian & $\begin{array}{c}\text { Calvo 1999, } \\
\text { Salgado et al. } 2004\end{array}$ & Rebbachisauridae & Forelimb \\
\hline $\begin{array}{c}\text { Muyelensaurus } \\
\text { pecheni }\end{array}$ & Argentina & $\begin{array}{c}\text { Late } \\
\text { Turonian }\end{array}$ & Coniacian & Calvo et al. $2007 \mathrm{~b}$ & Titanosauria & Forelimb \\
\hline $\begin{array}{l}\text { Qingxiusaurus } \\
\text { youjiangensis }\end{array}$ & China & Cenomanian & Maastrichtian & Mo et al. 2008 & Titanosauria & $\begin{array}{c}\text { Sternal plates, } \\
\text { humerus }\end{array}$ \\
\hline $\begin{array}{c}\text { Rinconsaurus } \\
\text { caudamirus }\end{array}$ & Argentina & $\begin{array}{c}\text { Late } \\
\text { Turonian }\end{array}$ & Coniacian & $\begin{array}{c}\text { Calvo and } \\
\text { González Riga } 2003\end{array}$ & Titanosauria & Forelimb \\
\hline $\begin{array}{c}\text { Sonidosaurus } \\
\text { saihangaobiensis }\end{array}$ & China & Turonian & Maastrichtian & Xu et al. 2006 & Titanosauria & Unknown \\
\hline $\begin{array}{c}\text { Sonidosaurus } \\
\text { saihangaobiensis }\end{array}$ & China & Turonian & Maastrichtian & Xu et al. 2006 & Titanosauria & Unknown \\
\hline
\end{tabular}

$15^{\circ}$ and $30^{\circ}$ mainly because of the atmospheric air convection Hadley Cells, which has remained stable since the Cretaceous (Jacobs et al. 2009a). Therefore, Iembe was an arid zone during the Turonian, which is further supported by the sediments at Iembe that show no signs of terrestrial productivity. A. adamastor was probably a sauropod adapted to arid/desert-like environment in a situation similar to the desert elephants today. RubilarRogers (2006) reported a Cretaceous titanosaur sauropod from the Atacama Desert (Chile), which is one of the oldest deserts on Earth. However, this material came from lacustrine deposits in Atacama.

\section{ACKNOWLEDGMENTS}

Many thanks to Eduardo Morais and Agostinho Vaz (Universidade Agostinho Neto), Manuel João Fonseca and Margarida Ventura (Universidade Privada de Angola), Nancy Stevens, Luís Rocha, Rosário Sarzedas, and Pedro Serrano for their support in the field. The field expeditions were funded by the Petroleum Research Institute, Institute for the Study of Earth and Man at Southern Methodist University in Dallas, National Geographic, TAP airlines, and Royal Netherlands Embassy in Luanda. Many thanks to Paul Upchurch 
and Phil Mannion for the comments in the phylogeny and anatomy. Preparation was conducted by O.M., A.S., Ricardo Araújo and C. Tomás. To João Marinheiro who edited some pictures.

\section{RESUMO}

Um membro anterior de um novo dinossauro saurópode ( $A n$ golatitan adamastor $\mathrm{n}$. gen. et $\mathrm{sp}$.) do Turoniano Superior de Iembe (Bengo) representa a descoberta do primeiro dinossauro em Angola e é uma das poucas ocorrências de dinossauros saurópodes na África Subsaariana recolhidos com bons controles cronológicos. Os sedimentos marinhos marginais de onde provém o espécime estão datados do Turoniano superior e, portanto, trata-se de um saurópodes não-titanossauro na África subsaariana onde predominavam titanossauros. Além disso, Angolatitan adamastor é o único Somphospondyli basal conhecido no Cretáceo Superior, o que implica a sobrevivência de formas-relíquia na África.

Palavras-chave: Angola, Cretáceo, Turoniano, dinossauros, sauropoda, Angolatitan.

\section{REFERENCES}

Antunes MT. 1961. Sur la Faune de vertébrés du Cretacé de Iembe (Angola). CR Acad Sciences Paris 253: 513-514.

ANTUNes MT. 1964. O Neocretácico e o Cenozóico do litoral de Angola. Junta de Investigações do Ultramar, 255 p.

Antunes MT And Cappetta H. 2002. Sélaciens du Crétacé (Albien-Maastrichtien) d'Angola. Palaeontographica 12: 85-146.

Apesteguía S. 2005. Evolution of the titanosaur metacarpus. Thunder-Lizards, The Sauropodomorph Dinosaur. Indiana University Press, p. 321-345.

BONAPARTE JF AND CORIA RA. 1993. Un nuevo y gigantesco sauropodo titanosaurio de la Formacion Rio Limay (Albiano-Cenomaniano) de la Provincia de Neuquén, Argentina. Ameghiniana 30(3): 271-282.

BONNAN MF AND WEDEL MJ. 2004. First occurrence of Brachiosaurus (Dinosauria: Sauropoda) from the Upper Jurassic Morrison Formation of Oklahoma. PaleoBios 24(2): 13-21.

Brownfield ME And Charpentier RR. 2006. Geology and total petroleum systems of the West-Central Coastal Province (7203), West Africa: US Geol Survey Bull 2207B, $52 \mathrm{p}$.
CAlvo JO. 1999. Dinosaurs and other vertebrates of the Lake Ezequiel Ramos Mexía area, Neuquén - Patagonia, Argentina in Proceedings of the Second Gondwanan Dinosaur Symposium, National Science Museum Monographs \#15, In: TOMIDA Y, Rich TH AND VicKeRsRICH P (Eds), Tokyo: $x+296$ p. P. 13-46.

Calvo JO and Bonaparte JF. 1991. Andesaurus delgadoi gen. et sp. nov. (Saurischia-Sauropoda), Dinosaurio Titanosauridae de la Formacion Rio Limay (AlbianoCenomaniano), Neuquén, Argentina. Ameghiniana 28(34): 303-310.

Calvo JO And GonzÁlez Riga BJ. 2003. Rinconsaurus caudamirus gen. et sp. nov., a new titanosaurid (Dinosauria, Sauropoda) from the Late Cretaceous of Patagonia, Argentina. Rev Geol Chile 30(2): 3-23. doi:10.4067/ S0716-02082003000200011. http://www.scielo.cl/ scielo.php?script=sci_arttext\&pid=S071602082003000200011\&lng=en\&nrm=iso\&tlng=en.

Calvo JO, GonzÁlez-Riga BJ And Porfiri JD. 2007b. A new titanosaur sauropod from the Late Cretaceous of Neuquén, Patagonia, Argentina. Arq Mus Nac 5(4): 485504.

Calvo JO, Porfiri JD, GonzÁlez-Riga BJ AND KellNER AWA. 2007a. A new Cretaceous terrestrial ecosystem from Gondwana with the description of a new sauropod dinosaur. An Acad Bras Cienc 79: 529-541.

Coward MP, Purdy EG, Ries AC And Smith DG. 1999. The distribution of petroleum reserves in basins of the South Atlantic margins. Geol Soc, London, Spec Publ 153(1): 101-131. (Available at http://www.google.com/ books?hl=pt-PT\&lr=\&id=YVooEivHwlMC).

CURRY Rogers K. 2009. The postcranial osteology of Rapetosaurus krausei (Sauropoda: Titanosauria) from the Late Cretaceous of Madagascar. J Vert Paleont 29: 1046-1086.

CUrry Rogers K AND Forster CA. 2001. The last of the dinosaur titans: a new sauropod from Madagascar. Nature 412: 530-534.

Gallina PA And Apesteguía S. 2005. Cathartesaura anaerobica gen. et sp. nov., a new rebbachisaurid (Dinosauria, Sauropoda) from the Huincul Formation (Upper Cretaceous), Rio Negro, Argentina. Rev Mus Argentino Cienc Nat 7: 153-166.

Gomani EM. 2005. Sauropod dinosaurs from the Early Cretaceous of Malawi. Paleontologica Electronica, http:// palaeo-electronica.org/2005_1/gomani27/issue1_05.htm.

Huene F. 1929. Los Saurisquios y Ornitisquios del Cretácico Argentino. Museo de la Plata, Anales 45(2). 
Jacobs Ll, Mateus O, Polcyn MJ, Schulp AS, Antunes MT, Morais ML and TAVARes T. 2006. The occurrence and geological setting of Cretaceous dinosaurs, mosasaurs, plesiosaurs, and turtles from Angola. J Paleo Soc Korea 22: 91-110.

Jacobs Ll, Mateus O, Polcyn MJ, Schulp AS, Scotese CR, Goswami A, Ferguson KM, RobBINS JA, VineyARd DP AND Neto AB. 2009a. Cretaceous paleogeography, paleoclimatology, and amniote biogeography of the low and mid-latitude South Atlantic Ocean. B Soc Geol Fr 180(4): 333.

Jacobs Ll, Polcyn MJ, Mateus O, Schulp AS And Neto AB. 2009b. The Cretaceous Skeleton Coast of Angola. J Vert Paleont 29(Suppl 3): 121A.

JANENSCH W. 1961. Die gliedmaszen und gliedmaszengürtel der Sauropoden der Tendaguru-schichten. Palaeontographica 3(Suppl 7): 177-235.

Kellner AWA ANd Azevedo SAK. 1999. A new sauropod dinosaur (Titanosauria) from the Late Cretaceous of Brazil. In: TOMIDA Y, RICH TH AND RICH PV, Proceedings of the Second Gondwanan Dinosaur Symposium. Natl Sci Mus Monographs 15: 111-142.

LinghaM-SOLIAR T. 1992. The tylosaurine mosasaurs (Reptilia, Mosasauridae) from the upper Cretaceous of Europe and Africa. Bull Inst R Sci Nat Belg Sci terre 62: 171-194.

LÜ J, AZuma Y, Chen R, ZHeng W AND Jin X. 2008. A new titanosauriform sauropod from the Early Late Cretaceous of Dongyang, Zhenjiang Province: Acta Geol Sin 82(2): 225-235.

LÜ J, Xu L, Zhang X, Hu W, Wu Y, Jia S AND Ji K. 2007. A new gigantic sauropod dinosaur with the deepest known body cavity from the Cretaceous of Asia. Acta Geol Sin 81(2): 167-176.

Mateus O, Jacobs LJ, Polcyn M, Schulp AS, Neto AB And Antunes MT. 2008. Dinosaur and turtles from the Turonian of Iembe, Angola In: LIVRo DE RESUMOS DE "TERCER CONGRESO LATINOAMERICANO De Paleontología de Vertebrados" 156 Neuquén, Argentina.

Mateus O, Jacobs LJ, Polcyn M, Schulp AS, VineYARD D, Neto AB And Antunes MT. 2009. The oldest African eucryptodiran turtle: Angolachelys mbaxi, from the Cretaceous of Angola. Acta Paleo Polonica 54(4): 581-588.

Martínez RD, Gimenez O, Rodriguez J, LunA M AND LAMANNA MC. 2004. An articulated specimen of the basal titanosaurian (Dinosauria: Sauropoda) Epach- thosaurus sciuttoi from the early Late Cretaceous Bajo Barreal Formation of Chubut Province, Argentina. J Vert Paleont 24(1): 107-120.

Mo Jin-You Jin-You, Mo Xin, Huang Chuo-Lin, ZhaO ZHONG-RU, WANG WeI AND XU. 2008. A new titanosaur (Dinosauria: Sauropoda) from the Late Cretaceous of Guangxi, China. Vertebrat PalAsiatic 46(2): $147-156$.

PANG Q AND Cheng Z. 2000. A new family of sauropod dinosaur from the Upper Cretaceous of Tianzhen, Shanxi Province, China. Acta Geol Sin 74(2): 117-125.

Polcyn M, Jacobs LJ, Mateus O AND Schulp AS. 2009. New specimens of Angolasaurus bocagei and comments on the early radiations of plioplatecarpine mosasaurs. J Vert Paleont 29(3): 165A.

RAUHut OWM AND Werner C. 1997. First record of Maastrichtian sauropod dinosaur from Egypt. Palaeo Africana 34: 63-67.

RoMer AS. 1956. Osteology of the reptiles. Chicago, University of Chicago, $772 \mathrm{p}$.

Rubilar-Rogers D. 2006. Titanosaurs from the Atacama Desert. J Vert Paleont 26(3): 117A.

Salgado L, Garrido A, Cocca SE AND Cocca JR. 2004. Lower Cretaceous rebbachisaurid sauropods from Cerro Aguada Del León, Neuquén Province, northwestern Patagonia, Argentina. J Vert Paleont 24(4): 903-912.

SChulp AS, Polcyn MJ, Mateus O, JaCOBS LJ AND Morais ML. 2008. A new species of Prognathodon (Squamata, Mosasauridae) from the Maastrichtian of Angola, and the affinities of the mosasaur genus Liodon. Proceedings of the Second Mosasaur Meeting, Fort Hays Studies Special Issue 3, Fort Hays State University, Hays, Kansas, p. 1-12.

Smith JB, Lamanna MC, Lacovara KJ, Dodson P, Smith JR, Poole JC, Giegengack R and AtTIA Y. 2001. A giant sauropod from an Upper Cretaceous Mangrove Deposit in Egypt. Science 292: 1704-1706.

Stromer E. 1932. Ergebnisse der Forschungsreisen Prof. E. Stromer in den Wüsten Ägyptens. II. Wirbeltier-Reste der Baharîjestufe (unterstes Cenoman). \#11. Sauropoda. Abh. Bayer. Akad. Wissensch. Math.-naturwiss. Abteilung 10: 1-21.

UPCHURCH P, BARRETT PM AND DODSON P. 2004. Sauropoda. p. 259-322 In: WeISHAMPEL DB, DODSON P AND OSMÓlsKA H (Eds), The Dinosauria, 2nd ed.

Weishampel DB, BARRETT PM, CORIA RA, LE LOEUFF J, Xu X, Zhao X, SAhni A, Gomani EMP and Noto CR. 2004. Dinosaur distribution, Chapter Twenty-four. 
In: Weishampel DB, Dodson P And Osmolska

H (Eds), The Dinosauria, 2nd ed., California University Press, p. 517-606.

Wilhite R. 2003. Biomechanical reconstruction of the appendicular skeleton in three North American Jurassic sauropods. Ph.D. dissertation. Louisiana State University, Baton Rouge, USA.

WILSON J. 2002. Sauropod dinosaur phylogeny: critique and cladistic analysis. Zool J [London] 136(2): 215-275.
Xu X, Zhang X, Tan Q, Zhao X And Tan L. 2006. A new titanosaurian sauropod from Late Cretaceous of Nei Mongol, China. Acta Geol Sin 80: 20-26.

You H, Ji Q, Lamanna MC, Li J And Li Y. 2004. A titanosaurian sauropod dinosaur with opisthocoelous caudal vertebrae from the Early Late Cretaceous of Liaoning Province, China: Acta Geol Sin 78(4): 907-911. 